\title{
EVALUATION OF OIL PALM LEAF-SPECIFIC PROMOTER (LSP1) ACTIVITY FOR EXPRESSING PHB GENES IN Arabidopsis thaliana
}

\author{
AYUB NOR HANIN*; MAT YUNUS ABDUL MASANI* and GHULAM KADIR AHMAD PARVEEZ*
}

\begin{abstract}
Production of polyhydroxybutyrate (PHB), a biodegradable plastic, in plant, has been studied all over the world. We have constructed a transformation vector pLSP15 carrying the PHB biosynthesis genes. Each of PHB genes was driven by an oil palm leaf-specific promoter (LSP1). This transformation vector was later transformed into Arabidopsis thaliana and successfully produced $T_{3}$ putative transgenic plants. The mature $T_{3}$ generation was analysed by Reverse Transcription-qPCR (RT-qPCR) to test the capability of a monocotyledon oil palm LSP1 promoter in driving the expression of the PHB genes in a dicotyledon A. thaliana plant. Expression of all PHB genes, i.e. phbA (2.32), phbB (1.53) and phbC (1.47) relative to the wild-type, were detected in the plant. Nile blue A staining demonstrated that the PHB polymer was successfully produced throughout the developmental stage of the transgenic A. thaliana plant without any deleterious effects. The results demonstrated that the oil palm LSP1 promoter could drive the expression of the PHB biosynthesis genes in plants.
\end{abstract}

Keywords: polyhydroxybutyrate, oil palm leaf-specific promoter, Arabidopsis thaliana transgenic plants, RT-qPCR.

Date received: 9 January 2015; Sent for revision: 12 January 2015; Received in final form: 18 September 2015; Accepted: 20 November 2015.

\section{INTRODUCTION}

Petroleum-based plastics are non-biodegradable polymers and have been widely used in industry and day-to-day applications for more than 90 years owing to their versatility and durability (Poirier et al., 1995; Rivard et al., 1995). For over 30 years, there has been a growing human concern about the use and development of biodegradable polymers due to the hazardous effect of the non-biodegradable plastic to the environment (Ojumu et al., 2004). Moreover, the increasing production cost and depletion of these valuable natural assets have created renewed incentive to search for sustainable alternatives (Keshavarz and Roy, 2010). These phenomena have

\footnotetext{
* Malaysian Palm Oil Board,

6 Persiaran Institusi, Bandar Baru Bangi,

43000 Kajang,Selangor, Malaysia.

E-mail: masani@mpob.gov.my
}

shifted the focus of research for the production of biodegradable plastics (bioplastics).

Bioplastics are natural biopolymers that are synthesised and catabolised by diverse organisms, and have certain advantages over petroleumderived plastics without causing noxious effects in the host (Suriyamongkol et al., 2007). Among the various types of bioplastics, polyhydroxyalkanoates (PHA) particularly polyhydroxybutyrate (PHB) and polyhydroxyvalerate (PHBV) are the most well-known since they are totally biosynthetic and biodegradable with zero toxic waste, and completely recyclable into organic waste (Williams and Peoples, 1996; Chanprateep, 2010).

PHB is a biodegradable polymer produced in many bacterial species, including Ralstonia eutropha (formerly known as Alcaligenes eutrophus), where it serves as a carbon source (Nawrath et al., 1994). The biosynthetic pathway of PHB has been studied in 
details using R. eutropha and three genes encoding the biosynthetic enzymes have been cloned (Peoples and Sinskey, 1989a, b). PHB production in R. eutropha is catalysed by three enzymes namely $\beta$-ketothiolase, acetoacetyl-CoA reductase and PHB synthase, which are encoded by the genes $p h b A, p h b B$ and $p h b C$, respectively. Nowadays, production of PHB in plants have been demonstrated in many plant species such as A. thaliana (Poirier et al., 1992; Nawrath et al., 1994), tobacco (Nakashita et al., 1999), corn (Zhong et al., 2003), tamarix (Endo et al., 2006) and sugar cane (Petrasovits et al., 2007). The production of PHB in plants would reduce the production cost because it does not require expensive fermentation equipment and substrates (Scheller and Conrad, 2005).

Studies by other groups have shown that the choice of the promoter to drive the expression of the PHB biosynthesis genes in plants affected the PHB yield and the plants phenotype. The use of a constitutive promoter such as the CaMV35S has caused growth retardation, leaf chlorosis and low transformation efficiencies (Poirier et al., 1992; Bohmert et al., 2000). These problems were eliminated by using other promoter systems such as an inducible promoter as demonstrated in transgenic $A$. thaliana (Bohmert et al., 2002). In transgenic flax, the use of a stem-specific promoter (14-3-3 promoter) to produce PHB does not affect the plant stem height (Wrobel et al., 2004). The use of a tissue-specific promoter will facilitate the production of PHA in an easily harvested tissue without disturbing the normal growth and development of plants (Masani et al., 2009).

The use of a tissue-specific promoter to drive the expression of all PHB genes was only studied in rape (Houmiel et al., 1999). In other plants such as A. thaliana, cotton and flax, only the phbA gene was attached to a tissue-specific promoter while $p h b B$ and $p h b C$ genes were under a constitutive promoter (Bohmert et al., 2002; John and Keller, 1996; Wrobel et al., 2004). This article reports the use of a multigene transformation vector to drive the expression of PHB genes in transgenic A. thaliana plants under the control of an oil palm leaf-specific promoter (LSP1). The results of expression of the PHB biosynthesis genes and production of the polymer in the transgenic A. thaliana plants will be presented and discussed. The effect of PHB synthesis on the phenotype of the transgenic $A$. thaliana plants will also be analysed.

\section{MATERIALS AND METHODS}

\section{Plant Materials}

The $\mathrm{T}_{3}$ generation of $A$. thaliana plants that have been transformed with pLSP15 vector (Figure 1) (Masani et al., 2009) by the Agrobacterium-mediated floral-dip method (Clough and Bent, 1998), were used in this analysis. The pLSP15 vector carried a

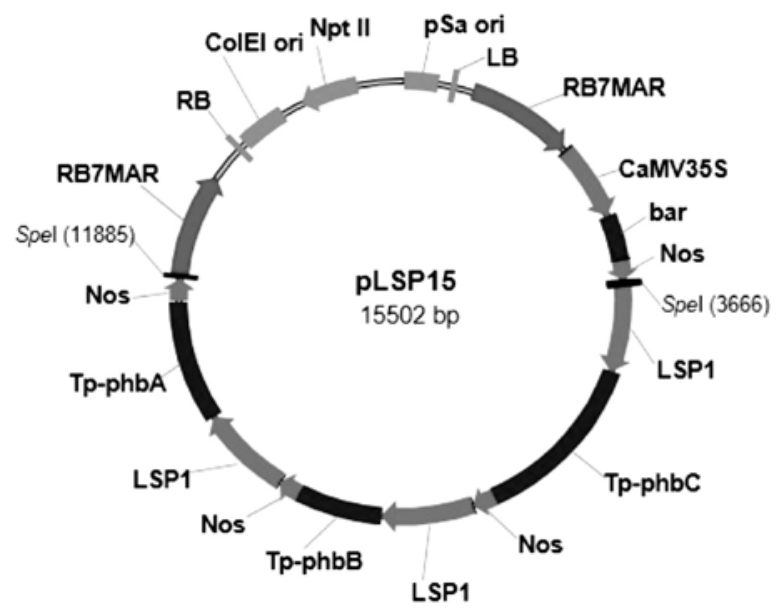

Figure 1. Schematic map of pLSP15 vector. LB: left border of T-DNA, RB7MAR: matrix attachment region of tobacco, CaMV35S: cauliflower mosaic virus $35 S$ promoter, bar: gene for phosphinothricin acetyltransferase, Nos: terminator of nos (nopaline synthase) gene, LSP1: leaf-specific promoter 1 of oil palm, Tp: transit peptide of oil palm $A C P$, phbA: $\beta$-ketothiolase, phbB: acetoacetyl-CoA reductase, phbC: PHBPHA synthase, RB: right border of T-DNA (reproduced from Masani et al., 2009).

Basta resistance gene (bar) driven by the CaMV35S promoter and each of the PHB genes ( $p h b A, p h b B$, $p h b C)$ was driven by an oil palm leaf-specific promoter (LSP1). Each of the PHB genes was fused with the transit peptide (Tp) of the oil palm acylcarrier-protein (ACP) (Rasid et al., 1999) to target the PHB proteins into the plastid.

\section{Polymerase Chain Reaction (PCR)}

Genomic DNA was extracted from leaves of A. thaliana using the DNeasy Plant Mini Kit (QIAGEN) according to the manufacturer's instruction. The putative transgenic $A$. thaliana plants were screened by $\mathrm{PCR}$ for the presence of $b$ ar gene using primers, BAR-F (5'-GGACTAGTGCCATGGCGGCGGTCTGC-3') and BAR-R (5'-GGACTAGT TCAGATCTCGGTGAC GGGC-3') according to Nurfahisza et al. (2014). The PCR condition used was as follow: the reaction mixture was initially heated at $95^{\circ} \mathrm{C}$ for $5 \mathrm{~min}$. Then the amplification was performed by 10 cycles at $95^{\circ} \mathrm{C}$ for $1 \mathrm{~min}, 70^{\circ} \mathrm{C}$ for $1 \mathrm{~min}$ and $72^{\circ} \mathrm{C}$ for $1 \mathrm{~min}$. The annealing temperature was reduced by $1.7^{\circ} \mathrm{C}$ in each cycle. The reaction was continued for 25 cycles of $95^{\circ} \mathrm{C}$ for $1 \mathrm{~min}, 53^{\circ} \mathrm{C}$ for $1 \mathrm{~min}$ and $72^{\circ} \mathrm{C}$ for $1 \mathrm{~min}$. The reaction mixture was subjected to a final extension of $72^{\circ} \mathrm{C}$ for $5 \mathrm{~min}$. PCR product was separated by electrophoresis in $1 \%(\mathrm{w} / \mathrm{v})$ agarose gel at $100 \mathrm{~V}$ and detected by ethidium bromide staining.

\section{Isolation and Quantification of Total Ribonucleic Acid (RNA)}

Total RNA was isolated from leaves of A. thaliana according to Zeng and Yang (2002) with 
modification. Isolated RNA were quantified spectrophotometrically (NanoDrop ND-1000; NanoDrop Technologies Inc. USA) with absorbance at $260 \mathrm{~nm}$. The integrity of RNA was checked by electrophoresis on a $1 \%(\mathrm{w} / \mathrm{v})$ agarose gel and ethidium bromide staining.

\section{DNase Treatment, RNA Integrity Analysis and cDNA Synthesis}

The DNase treatment was carried out using RNase Free DNase Set (QIAGEN) according to the manufacturer's protocol. The concentration of DNase-treated RNA was determined using the NanoDrop ND-1000 spectrophotometer (NanoDrop Technologies Inc. USA). The DNase-treated RNA samples were subjected to integrity analysis using the Agilent 2100 Bioanalyser (Agilent Technologies, USA). Intact total RNA was converted to cDNA using High Capacity cDNA Archive Kit (Applied Biosystems, USA) according to the manufacturer's protocol.

\section{Reverse Transcription-qPCR (RT-qPCR)}

Analysis for conserved regions that were used for primer and probe synthesis was performed using Vector NTI software (Invitrogen Corporation, USA). All oligonucleotides (Table 1) for the TaqMan Assay were designed by Primer Express software (Applied Biosystems, USA). The internal probe specific for each gene was labelled at the $5^{\prime}$ end with dye 6-carboxyfluorescein (FAM) and the 3' end was labelled with the non-flourescent quencher (NFQ).

The RT-qPCR was carried out in mixtures containing 1x TaqMan Universal PCR Master Mix, 1x Assay Mix (containing specific primers and probe) and $45 \mathrm{ng}$ of template cDNA. The Arabidopsis actin (ACT2) gene was also amplified as the endogenous control. A PCR no-amplification control was set up with water instead of template. The PCR cycling parameters were $50^{\circ} \mathrm{C}$ for $2 \mathrm{~min}, 95^{\circ} \mathrm{C}$ for $10 \mathrm{~min}$, and 40 cycles at $95^{\circ} \mathrm{C}$ for $15 \mathrm{~s}$ and $60^{\circ} \mathrm{C}$ for $1 \mathrm{~min}$. Real-time detection of fluorescence was performed on the ABI PRISM 7000 Sequence Detection System (Applied Biosystems, USA). Relative quantification (RQ) of the gene expression and statistical analysis were calculated using the RQ Study Application in the 7000 System SDS software version 1.2.3 (Applied Biosystems, USA). The RT-qPCR analysis for each gene was run in triplicates.

The efficiency of the TaqMan reaction was determined by the method described by Toplak et al. (2004). A five serial 10-fold dilutions of a positive control template was carried out and the Cq values were plotted as a function of $\log _{10}$ concentration of template. The slope of the resulting line is a function of the PCR efficiency. The PCR efficiency was calculated by replacing the slope (S) value into the following equation: PCR efficiency $(\%)=$ $\left\{\left[10^{(1 /-5)]}-1\right\} \times 100\right.$. The cDNA generated from the $R$. eutropha were used as the positive control template for all the PHB genes while cDNA generated from wild type Arabidopsis were used to generate the standard curve for the ACT2 gene.

\section{Nile Blue A Staining Method}

Nile blue A staining was performed according to Ostle and Holt (1982) with some modifications. A 1\% $(\mathrm{w} / \mathrm{v})$ staining solution of Nile blue A (Sigma) was prepared by heating at $50^{\circ} \mathrm{C}$ to dissolve the stain, and then filtered before use. Plant samples were cut into small square sections and put on a glass slide. Then $500 \mu \mathrm{l}$ Nile blue A solution was added and incubated at $55^{\circ} \mathrm{C}$ for $10 \mathrm{~min}$. The slides were washed with sterile water followed with $8 \%(\mathrm{v} / \mathrm{v})$ acetic acid. The slides were washed again with sterile water, blotted dry on Whatman paper, and then covered with a glass cover slip. The stained samples were

TABLE 1. LIST OF PRIMERS AND PROBES FOR REAL-TIME POLYMERASE CHAIN REACTION (PCR)

\begin{tabular}{clc}
\hline Genes & Sequence $\left(\mathbf{5}^{\prime} \mathbf{-} \mathbf{3}^{\prime}\right)$ & $\begin{array}{c}\text { Amplicon } \\
\text { size (bp) }\end{array}$ \\
\hline \multirow{2}{*}{$p h b A$} & $\begin{array}{l}\text { F: GTCCCGGTGGTGAGCAA } \\
\text { R: GTGCTCGTCGGTGTCGA }\end{array}$ & \\
& FAM-CAAGGGCGACGTGACCT-NFQ & \\
\multirow{2}{*}{$p h b B$} & F: CCGCCAGGACGTGCT & 55 \\
& R: GCCCAGGCGCTTGAC & \\
& FAM-TCGCGACGATCTTGTC-NFQ & \\
$p h b C$ & F: TGGACCGCGGCCTATG & \\
& R: ACGCACCCAGCACGAA & \\
& FAM-CTGCTGGCGAACAAG-NFQ & \\
ACT2 & F: TCCTTTGTTGCTGTTGACTACGA & \\
& R:GCCCATCGGGTAATTCATAGTTCTT & \\
& FAM-CTGGTCTTTGAGGTTTCCAT-NFQ & \\
\hline
\end{tabular}


viewed under an excitation wavelength of $460 \mathrm{~nm}$ by using Leica stereomicroscope (Model MZ12.5). A fluorescence Plus filter module (Leica) was used to reduce autofluorescence from chlorophyll.

\section{RESULTS AND DISCUSSION}

\section{Screening of the Transgenic Plants by PCR Analysis}

The PCR method was used to pre-screen the putative transgenic $A$. thaliana plants using specific primers for the bar gene. A 300-bp bar internal fragment was amplified using total DNA isolated from leaves of the plants regenerated from the Basta-resistant seed (Figure 2). No PCR products were observed in untransformed $A$. thaliana plants. The presence of the bar gene indicated that the PHB genes ( $p h b A, p h b B, p h b C$ ) might also be present in the transgenic $A$. thaliana because these genes are linked in tandem in pLSP15 plasmid (Masani et al., 2009).

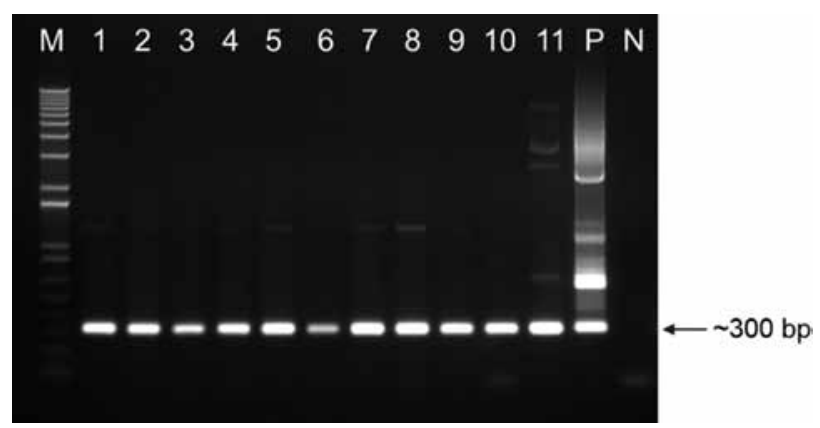

Figure 2. Polymerase chain reaction (PCR) analysis of genomic DNA from the $T_{3}$ transgenic $A$. thaliana using primers specific for the bar gene. A 300 bp PCR product corresponding to the bar gene was detected in the transgenic samples (lanes 1-11) but not in the wild type A. thaliana (lane N). Lane M: $1 \mathrm{~kb}$ plus DNA ladder (Invitrogen); lanes 1-11: transgenic A. thaliana; Lane N: wild type A. thaliana; Lane P: positive control ( $p L S P 15$ plasmid).

\section{Transgene Expression Analysis by Reverse- transcription-qPCR}

The reverse transcription-qPCR (RT-qPCR) analysis was used to determine the expression levels of mRNA from the transcription of the $p h b A$, $p h b B$ and $p h b C$ genes. The RT-qPCR was chosen because it is the most effective and sensitive method for determining expression levels and quantities of certain genes even though from minute quantities of RNA (Muller et al., 2002; Pfaffl, 2001). In addition, this method has advantages of wide dynamic range of quantification, and does not require post-PCR handling, hence, preventing the possibility of crosscontamination (Bustin, 2002).

Since the RNA integrity is very important in gene expression study, we only used the RNA sample with RNA integrity number (RIN) value greater than 5.0 (data not shown) from the bioanalyser analysis to synthesise cDNA. This is based on a study by Fleige and Pfaffl (2006) who recommended that RIN value higher than five as a good RNA quality. They also suggested that an RIN value of more than eight as a perfect value of RNA to be used for downstream application. The standard curves for the efficiency tests of $p h b A, p h b B, p h b C$ and $A C T 2$ genes are shown in Figure 3. All standard curves demonstrated a linear quantification over a range of $5 \log$ units for all the genes, indicating a wide dynamic range and high reliability. Slopes of $-3.213(p h b A),-3.342(p h b B)$, $-3.199(p h b C)$ and $-3.273(A C T 2)$ indicated that the PCR reactions were 105\%, 99\%, 105\% and 102\% efficient, respectively. A slope of $-3.3 \pm 10 \%$ reflects an efficiency of $100 \% \pm 10 \%$. A PCR reaction with lower efficiency will have lower sensitivity. Generally, an efficiency value between $90 \%$ and $110 \%$ is considered acceptable (Applied Biosystems, 2011).

The RQ Study Application that was used to quantify the relative gene expression was based on the $2^{-\Delta \mathrm{Cq}}$ method developed by Livak and Schmittgen (2001). The quantification cycle $\left(C_{q}\right)$ values obtained from the amplification plot were used to estimate the relative abundance of the genes. The value marks the first cycle at which the signal is significantly above the background. Then, the average $C_{q}$ values for the target gene were normalised to the average $\mathrm{C}_{\mathrm{q}}$ values of the endogenous control (ACT2). Finally, the comparative $C_{\mathrm{q}}$ values $\left(\Delta \Delta \mathrm{C}_{\mathrm{q}}\right)$ were obtained by subtracting the $\Delta \mathrm{C}_{\mathrm{q}}^{\mathrm{q}}$ of calibrator sample from $\Delta \mathrm{C}_{\mathrm{q}}$ of test sample. The relative quantification $(R Q)$ of target gene expression was calculated using the $\Delta \Delta C_{q}$ values according to the Equation $2^{-\Delta \mathrm{Cq}}$. Fold-differences were expressed as log values of RQ values.

Figure 4 shows the relative amount of the $p h b A, p h b B$ and $p h b C$ transcript using the wild type $A$. thaliana as the calibrator. The fold changes of expression of the $p h b A, p h b B$ and $p h b C$ genes were normalised to the expression of the ACT2 gene (endogenous reference gene) and relative to the expression of the $p h b A, p h b B$ and $p h b C$ genes in wild-type $A$. thaliana (calibrator). In qPCR, normalisation is an essential component because this process normalises the variation in the amount of RNA or cDNA added to the qPCR reaction (Livak and Schmittgen 2001; Bustin et al., 2009). The ideal gene for normalisation should be expressed at a constant level among different type of tissues at all phases of development, and should not be affected by the experimental procedure (Bustin, 2000). The transgenic $A$. thaliana namely ARPHB3 showed detectable levels of $p h b A, p h b B$ and $p h b C$ transcripts. Although all the PHB genes were driven by the LSP1 promoter, the expression levels were varied among the three genes. The expression level of the $p h b A$ gene was the highest (2.32), followed by the $p h b B$ (1.53) and then $p h b C$ (1.47) genes relative to the wild- 
a)

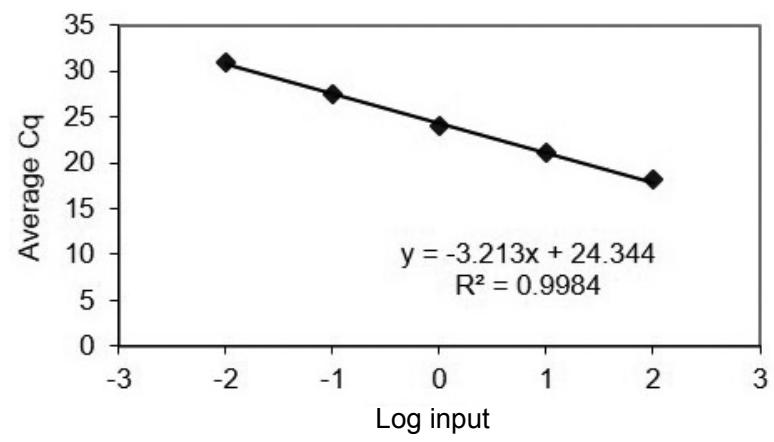

- phbA Linear (phbA)

c)

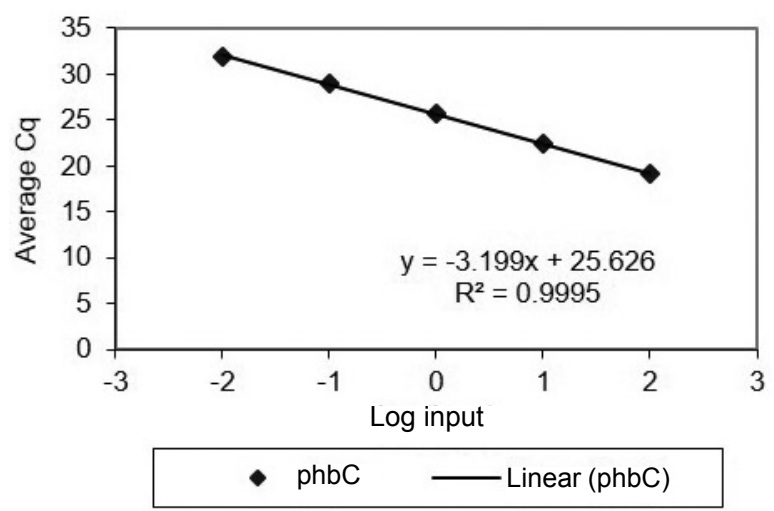

b)

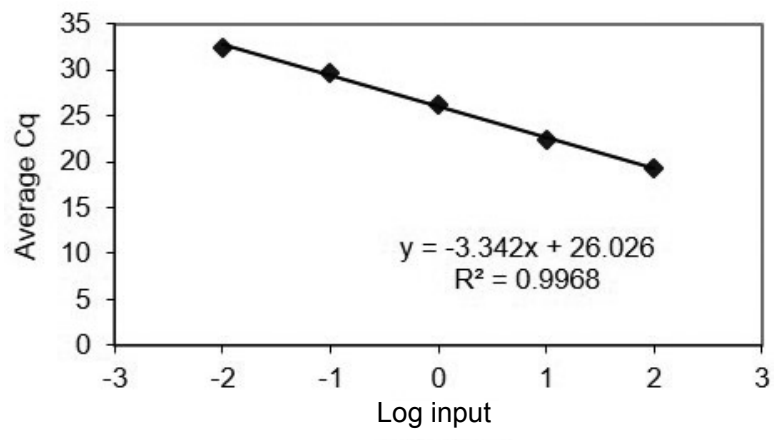

- phbB Linear (phbB)

d)

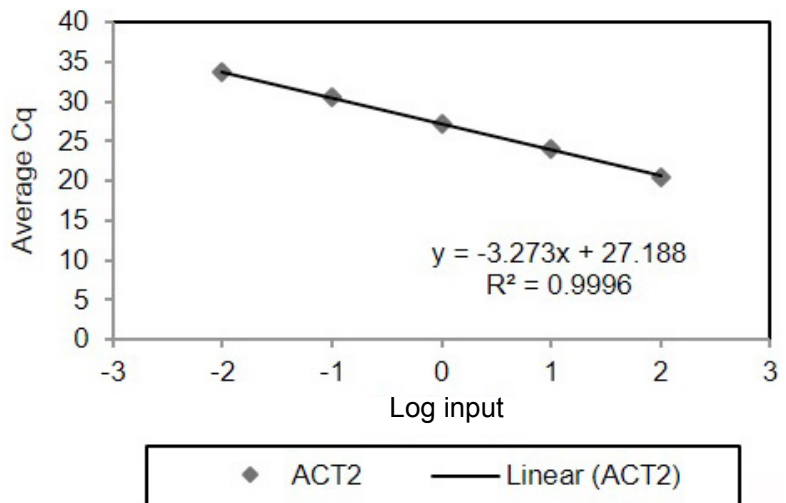

Figure 3. The standard curves of the polymerase chain reaction (PCR) efficiency test for genes of phbA (a), phbB (b), phbC (c) and ACT2 (d). A five serial 10-fold dilutions of a positive control template was carried out and the $C_{q}$ values was plotted as a function of $\log _{10}$ concentration of template. The slope of the resulting line is a function of the PCR efficiency.

type. The expression patterns of all the PHB genes were similar to findings from other studies (Purnell et al., 2007; Somleva et al., 2008; Parveez et al., 2015) where they found that in the PHB producing plants, the expression of $p h b C$ was the lowest among the three genes even though the genes were controlled by the same promoter.

The detection of all the transcripts required for PHB synthesis demonstrated that the LSP1 promoter was efficient to drive the expression of the PHB genes in A. thaliana. These results also depicted that a promoter from monocotyledon plants such as oil palm could drive gene expression in dicotyledon plants such as A. thaliana. Other than the LSP1 promoter, another promoter from oil palm known as the translationally control tumour protein (TCTP) promoter, was also proven to drive the expression of gusA gene in tobacco leaves (Masura et al., 2011). The $C a t B$ promoter, isolated from the rice catalase gene was not only able to drive the expression of gus A gene in rice, but also in tobacco and A. thaliana (Iwamoto et al., 2004). Previously, Khan et al. (2001) have also reported that the corn ubiquitin promoter strongly expressed an insecticidal cry gene of Bacillus thuringiensis in tobacco plants which makes them resistant to American bollworm (Heliothis armigera).

\section{PHB Formation in A. thaliana Leaves}

Nile blue staining technique was used to determine whether the transcripts of $p h b A, p h b B$ and $p h b C$ genes were able to produce the PHB polymer. The Nile blue staining was commonly used as the early evidence of the accumulation of PHB polymer in the transgenic plants (Somleva et al., 2013). In Nile blue-stained sections from fully developed mature leaves of $A$. thaliana plants, fluorescent granular inclusions were observed in transgenic plants but not in the wild type (Figure 5). This was due to Nile blue A binding to PHB granule diffuses strong orange fluorescence by excitation at wavelength of $460 \mathrm{~nm}$. Autofluorescence of trace chlorophyll was not observed since the chlorophyll has been removed by washing with $8 \%(\mathrm{v} / \mathrm{v})$ acetic acid in addition to the use of Plus filter module (Leica), which blocked the emission of chlorophyll autofluorescence. Furthermore, cell membranes or other lipid-containing cell components do not 


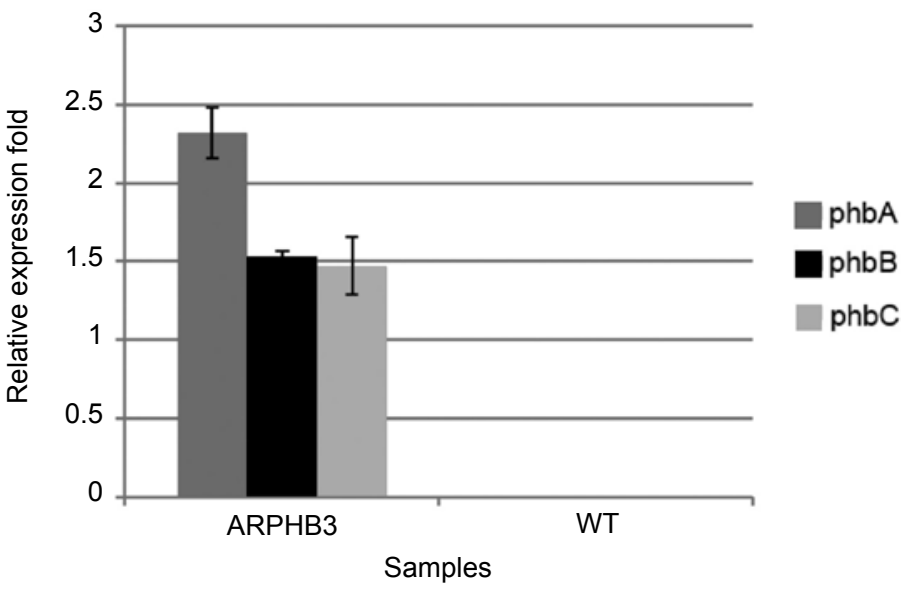

Figure 4. Relative expression folds of $\mathrm{phbA}$, phbB and phbC genes in transgenic A. thaliana (ARPHB3) obtained by the RT-qPCR analysis. The wild type A. thaliana (WT) was used as the calibrator.
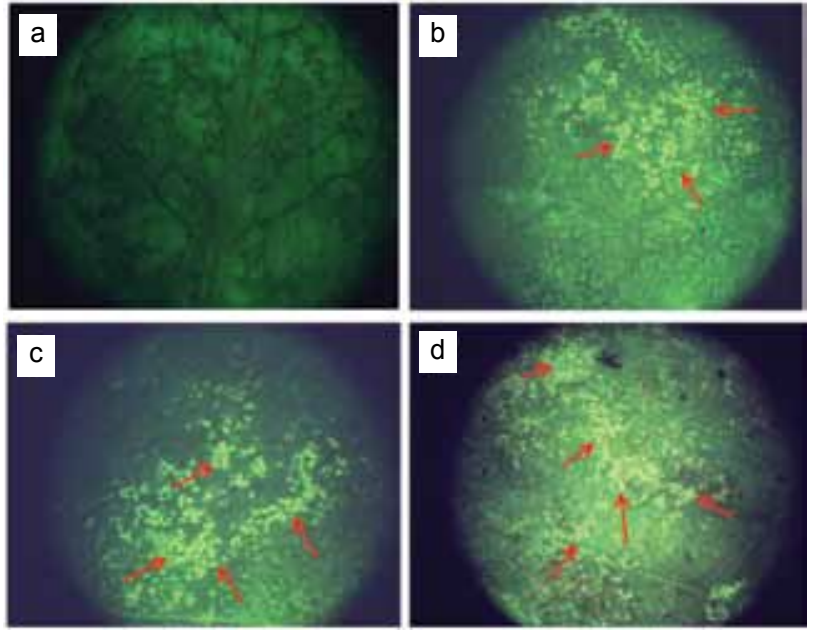

Figure 5. Epifluorescence microscopy of polyhydroxybutyrate (PHB) granules in the leaf of plants stained with Nile blue A. The Nile blue A-stained leaf (surface) was photographed with fluorescence $(460 \mathrm{~nm})$. Foci of orange fluorescence represent PHB granules. Red arrows indicate high intensity of orange fluorescence. (a): wild type A. thaliana, (b): 12 weeks of ARPHB3, (c): 16 weeks of ARPHB3 and (d): 20 weeks of ARPHB3.

absorb Nile blue A to give detectable fluorescence as shown in Figure $5 a$ for wild type leaf samples, which could result in a false positive.

The number of granules increased in line with the maturity of the leaves indicating accumulation of the PHB polymer throughout the developmental stage of the $A$. thaliana plant (Figures $5 b$ to $5 d$ ). This result is in accordance with other studies which also indicated that the accumulation of PHB granule being the lowest in the youngest leaves and increasing with the leaf age (Purnell et al., 2007; Somleva et al., 2008; Petrasovits et al., 2012). The PHB fluorescence granules were abundantly distributed throughout the leaf of palisade chlorophyll rather than sponge mesophyll. In contrast, no fluorescence granule was exhibited in veins, midrib and petiole. This was expected since the oil palm LSP1 promoter is derived from light-harvesting chlorophyll $a / b$ binding protein (LHCB) gene of oil palm, which is abundantly expressed in green leaves of oil palm, particularly tissues packed with chloroplasts (Chan et al., 2008). Taken together, these results suggested that the LSP1 promoter could consistently drive the expression of the PHB genes throughout the growth of $A$. thaliana plant.

\section{Effect of PHB Production on Plant Growth and Development}

Previous studies have demonstrated retardation of plant growth when a strong constitutive promoter was used to drive the expression of PHB genes (Poirier et al., 1992; Wrobel et al., 2004). In this study, mature $\mathrm{T}_{3}$ transgenic $A$. thaliana plants showed normal growth, but the number of seeds was slightly lower than the wild-type plants (Figure 6). This result suggested that the use of a leaf-specific promoter could protect $A$. thaliana from abnormal growth. Similarly, fertile PHB producing plants were obtained when Nawrath et al. (1994) transformed the A. thaliana plants with PHB genes driven by seedspecific promoter of the $12 \mathrm{~S}$ seed storage protein of A. thaliana. John and Keller (1996) also reported that the transgenic cotton plants exhibited normal growth after transformation of PHB genes driven by a fibre-specific promoter. Wrobel et al. (2004) also reported that the use of a stem-specific promoter driving PHB genes yielded high amount of PHB without any penalty to the transgenic flax plant growth as was observed when the same gene was driven by CaMV35S promoter.

In early generation of $\mathrm{PHB}$ producing transgenic plants, PHB enzymes were targeted to the cytoplasm, a place of many essential metabolic pathways. Reduction of metabolites from these important metabolic pathways of cytoplasm may have been the cause of harmful effects of PHB production 


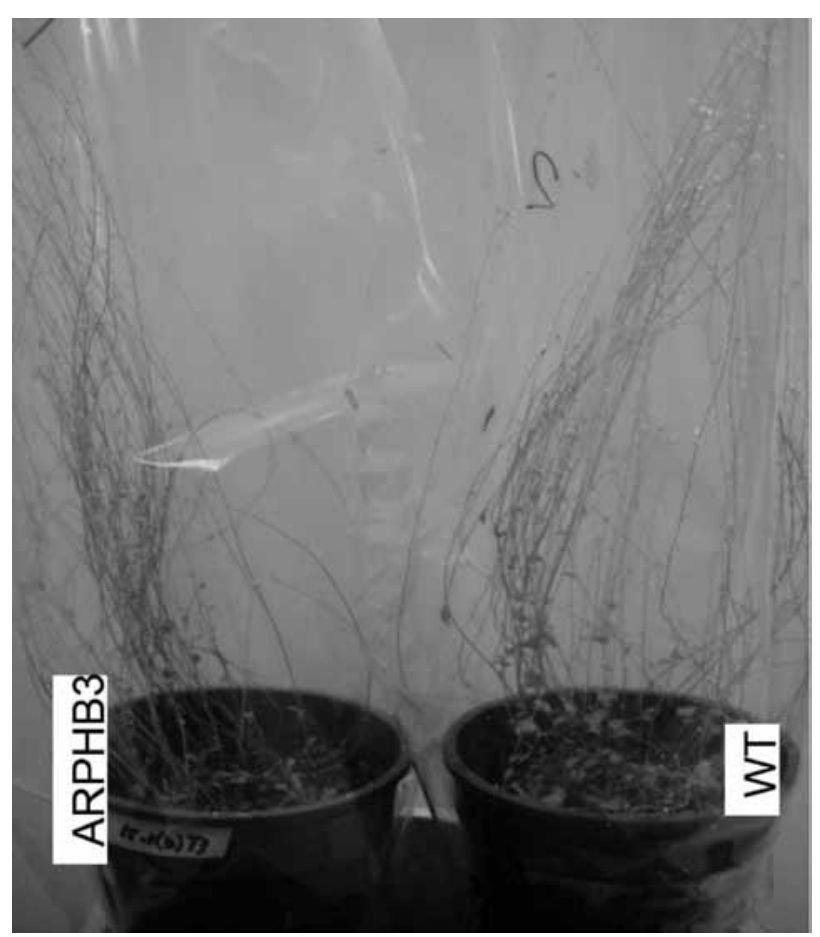

Figure 6. Growth and phenotype of the PHB producing transgenic A. thaliana (ARPHB3) compared to the wild-type Arabidopsis (WT). The mature $T_{3}$ transgenic $\mathrm{A}$. thaliana plant showed normal phenotype but the number of seeds were less than the control.

(Poirier et al., 1992). In our experiment, the expression of the PHB genes was controlled by the leaf-specific promoter (LSP1) and enzymes for PHB production were targeted to the plastids of leaves. In the plastids of leaves, the polymer precursor acetylCoA is mainly used as the precursor of membrane lipid biosynthesis. The normal growth of the $T_{3}$ A. thaliana indicated that the supply of acetyl-CoA was sufficient for both PHB and membrane lipid biosynthesis (Poirier et al., 1992). In addition, the generation of normal transgenic plants suggested that PHB accumulation is well tolerated by these plants (Somleva et al., 2008).

A lower seed production from the mature $\mathrm{T}_{3}$ transgenic $A$. thaliana could possibly be due to an elevated expression of the phbB genes (Figure 4). Poirier et al. (1992) reported that a high expression level of acetoacetyl-CoA reductase $(p h b B)$ in transgenic $A$. thaliana plants caused a consequential reduction in $45 \%$ seed production compared to wildtype plants. This could be the results of diversion of a significant amount of acetyl-CoA or acetoacetylCoA away from an important biochemical pathway such as isoprenoid biosynthesis (Kirby and Keasling, 2009).

\section{CONCLUSION}

In this article, we report successful transformation of $A$. thaliana with PHB genes driven by an oil palm leaf-specific promoter (LSP1). The expression of $p h b A, p h b B$ and $p h b C$ genes could be observed in the leaves of mature $\mathrm{T}_{3}$ plants. The plant also produced PHB in the leaves without any negative effect on the plant growth. These results will open the path to engineer the production of $\mathrm{PHB}$, specifically in plant leaves. This study also demonstrated that the use of RT-qPCR and Nile blue staining could be applied to oil palm genetic engineering programme especially on the production of PHB in oil palm. Through this programme, thousands of embryogenic calli have been bombarded with PHB genes and hundreds of the putative transgenic plants have been obtained (Parveez et al., 2008; 2015; Yunus et al., 2008; Masani et al., 2009). By using RT-qPCR and Nile blue staining, the putative transgenic oil palm producing PHB could be efficiently evaluated in shorter time compared to conventional molecular analyses such as Southern and Western blot hybridisation.

\section{ACKNOWLEDGEMENT}

The authors wish to thank the Director-General of MPOB for permission to publish this article. We also thank the Massachusetts Institute of Technology (MIT), USA for providing the PHB genes. This research was funded by the Ministry of Science, Technology and Innovation, Malaysia under the Malaysia-MIT Biotechnology Partnership Programme (MMBPP) and MPOB's in vitro Transformation of Oil Palm Programme.

\section{REFERENCES}

APPLIED BIOSYSTEM (2011). Real-time PCR: understanding $\mathrm{C}_{\mathrm{t}}$. Application note. http:// www.lifetechnologies.com / my / en / home/lifescience / pcr / real-time-pcr / qpcr-education / pcrunderstanding-ct-application-note.html

BOHMERT, K ; BALBO, I ; KOPKA, J ; MITTENDORF, V; NAWRATH, C; POIRIER, Y; TISCHENDORF, G; TRETHEWY, R N and WILLMITZER, L (2000). Transgenic Arabidopsis plants can accumulate polyhydroxybutyrate to up to $4 \%$ of their fresh weight. Planta., 211: 841-845.

BOHMERT, K; BALBO, I; STEINBÜCHEL, A; TISCHENDORF, G and WILLMITZER, L (2002). Constitutive expression of the $\beta$-ketothiolase gene in transgenic plants. A major obstacle for obtaining polyhydroxybutyrate-producing plants. Plant Physiol., 128: 1282-1290.

BUSTIN, S A (2000). Absolute quantification of mRNA using real-time reverse transcription polymerase chain assays. J. Mol. Endocrinol., 25: 169 $-193$. 
BUSTIN, S A (2002). Quantification of mRNA using real-time reverse transcription PCR (RT-PCR): trends and problems. J. Mol. Endocrinol., 29: 23-39.

BUSTIN, S A; BENES, V; GARSON, J A; HELLEMANS, J; HUGGET, J; KUBISTA, M; MUELLER, R; NOLAN, T; PFAFFL, M W; SHIPLEY, G L; VANDESOMPELE, J and WITTWER, C T (2009). The MIQE guidelines: minimum information for publication of quantitative real-time PCR experiments. Clin. Chem., 55: 611-622.

CHAN, P L; SITI NOR AKMAR, A and ROOHAIDA, O (2008). Light-harvesting clorophyll A/B binding protein (LHCB) promoter for targeting specific expression in oil palm leaves. J. Oil Palm Res. (Special Issue July 2008): 21-29.

CHANPRATEEP, S (2010). Current trends in biodegradable polyhydroxyalkanoates. J. Biosci. Bioeng., 110: 621-632.

CLOUGH, S J and BENT, A F (1998). Floral dip: a simplified method for Agrobacterium-mediated transformation of Arabidopsis thaliana. Plant J., 16: 735-743.

ENDO, N; YOSHIDA, K; AKIYOSHI, M and MANJI, $S$ (2006). Hybrid fiber production: a wood and plastic combination in transgenic rice and Tamarix made by accumulating poly-3-hydroxybutyrate. Plant Biotechnol., 23: 99-109.

FLEIGE, S and PFAFFL, M W (2006). RNA integrity and the effect on the real-time qRT-PCR performance. Mol Aspects Med., 27: 126-139.

HOUMIEL, K L; SLATER, S; BROY LES, D; CASAGRANDE, L; COLBURN, S; GONZALEZ, K; MITSKY, T A; REISER, S E; SHAH, D; TAYLORM, N B; TRAN, M; VALENTIN, H E and GRUYS, K J (1999). Poly ( $\beta$-hydroxybutyrate) production in oilseed leukoplasts of Brassica napus. Planta, 209: 547-550.

IWAMOTO, M; HIGO, H and HIGO, K (2004). Strong expression of the rice catalase gene $C a t B$ promoter in protoplasts and roots of both a monocot and dicots. Plant Physiol. Biochem., 42: 241-249.

JOHN, M E and KELLER, G (1996). Metabolic pathway engineering in cotton: biosynthesis of polyhydroxybutyrate in fiber cells. Proc. Natl. Acad. Sci. USA., 93: 12768-12773.

KESHAVARZ, T and ROY, I (2010). Polyhydroxyalkanoates: bioplastic with green agenda. Curr. Opin. Microbiol., 13: 321-326.
KHAN, M A; MAKHDOOM, R; HUSNAIN, T; SALEEM, M Z; MALIK, K; LATIF, Z; ALTOSAAR, I and RIAZUDDIN, S (2001). Expression of Bt gene in a dicot plant under promoter derived from a monocot plant. Pak. J. Biol. Sci., 4(12): 1518-1522.

KIRBY, J and KEASLING, J D (2009). Biosynthesis of plant isoprenoids: perspectives for microbial engineering. Annu. Rev. Plant Biol., 60: 335-355.

LIVAK, K J and SCHMITTGEN, T D (2001). Analysis of relative gene expression data using real-time quantitative PCR and the $2^{-\Delta \Delta C}$ method. Methods., 25: 402-408.

MASANI, M Y A; PARVEEZ, G K A; IZAWATI, A M D; CHAN, P L and SITI NOR AKMAR, A (2009). Construction of PHB and PHBV multiple-gene vectors driven by an oil palm leaf-specific promoter. Plasmid., 62: 191-200.

MASURA, S S; PARVEEZ, G K A and LOW, E T L (2011). Isolation and characterization of an oil palm constitutive promoter derived from a translationally control tumor protein (TCTP) gene. Plant Physiol. Biochem., 49: 701-708.

MULLER, P Y; JANOVJAK, H; MISEREZ, A R and DOBBIE, Z (2002). Processing of gene expression data generated by quantitative real-time RT-PCR. BioTechniques., 32: 1372-1379.

NAKASHITA, H; ARAI, Y; YOSHIOKA, K; FUKUI, T; DOI, Y; USAMI, R; HORIKOSHI, K and YAMAGUCHI, I (1999). Production of biodegradable polyester by a transgenic tobacco. Biosci. Biotechnol. Biochem., 63: 870-874.

NAWRATH, C; POIRIER, $Y$ and SOMERVILLE, C (1994). Targetting of the polyhydroxybutyrate biosynthetic pathway to the plastids of Arabidopsis thaliana results in high levels of polymer accumulation. Proc. Natl. Acad. Sci. USA., 91: 12760-12764.

NURFAHISZA, A R; RAFIQAH, M A; ABDUL MASANI, M Y; NOR HANIN, A A; RASID, O A; PARVEEZ, G K A and ISMANIZAN, I (2014). Molecular analysis of transgenic oil palm to detect the presence of transgenes. J. Oil Palm Res. Vol. 26: 73-80.

OJUMU, T V; YU, J and SOLOMON, B O (2004) Production of polyhydroxyalkanoates, a bacterial biodegradable polymer. Afr. J. Biotechnol., 43: 18-24.

OSTLE, A G and HOLT, J G (1982). Nile blue A as a fluorescent stain for poly- $\beta$-hydroxybutyrate. Appl. Environ. Microbiol., 44(1): 238-241. 
PARVEEZ, G K A; BAHARIAH, B; AYUB, N H; MASANI, M Y A; RASID, O A; TARMIZI, A H and ISHAK, Z(2015). Production of polyhydroxybutyrate in oil palm (Elaeis guineensis Jacq.) mediated by microprojectile bombardment of PHB biosynthesis genes into embryogenic calli. Front. Plant Sci. 6: 598.

PARVEEZ, G K A; BAHARIAH, B; NOR HANIN, A; MASANI, A M Y; TARMIZI, A H; ZAMZURI, I; AHMAD KUSHAIRI, D; YORK, G, JO, Y B and SINSKEY, A J (2008). Transformation of PHB and PHBV genes driven by maize ubiquitin promoter into oil palm for the production of biodegradable plastics. J. Oil Palm Res. (Special Issues 2008): 76-86.

PEOPLES, O P and SINSKEY, A J (1989a). Poly- $\beta$ hydroxybutyrate biosynthesis in Alcaligene eutrophus H16. Characterisation of the genes encoding $\beta$-ketothiolase and acetoacetyl-CoA reductase. J. Biol. Chem., 264: 15293-15297.

PEOPLES, O P and SINSKEY, A J (1989b). Poly- $\beta$ hydroxybutyrate biosynthesis in Alcaligene eutrophus H16. Identification and characterisation of the PHB polymerase (phaC). J. Biol. Chem., 264: 15298-15303.

PETRASOVITS, L A; PURNELL, M P; NIELSEN, L K and BRUMBLEY, S M (2007). Production of polyhydroxybutyrate in sugarcane. Plant Biotechnol. J., 5: 162-172.

PETRASOVITS, L A; ZHAO, L; MCQUALTER, R B; SNELL, K D; SOMLEVA, M N; PATTERSON, N A; NIELSEN, L K and BRUMBLEY, S M (2012). Enhanced polyhydroxybutyrate production in transgenic sugarcane. Plant Biotechnol. J., 10: 569-578.

PFAFFL, M W (2001). A new mathematical model for relative quantification in real time RT-PCR. $\mathrm{Nu}$ cleic Acids Res., 29: 2002-2007.

POIRIER, Y; DENNIS, DE; KLOMPARENS, K and SOMERVILLE, C (1992). Polyhydroxybutyrate, a biodegradable thermoplastic, produced in transgenic plants. Science 256: 520-523.

POIRIER, Y; NAWRATH, C and SOMERVILLE, C (1995). Production of polyhydroxyalkanoates, family of biodegradable plastics and elastomers, in bacteria and plants. Biotechnol., 13: 142-150.

PURNELL, M P; PETRASOVITS, L A; NIELSEN, L K and BRUMBLEY, S M (2007). Spatio-temporal characterisation of polyhydroxybutyrate accumulation in sugarcane. Plant Biotechnol. J., 5: 173-184.

RASID, O A; CHEAH, S C and MOHD ARIF, A M (1999). Isolation and sequencing of cDNA clones coding for oil palm (Elaeis guineensis) acyl carrier protein (ACP). J. Oil Palm Res. (Special Issue 1999): 88-95.
RIVARD, C; MOENS, L; ROBERTS, K; BRIGHAM, J and KELLEY, S (1995). Starch esters as biodegradable plastics: effects of ester group chain length and degree of substitution on anaerobic biodegradation. Enzyme and Microbial. Tech., 17: 848-852.

SCHELLER, J and CONRAD, U (2005). Plant-based material, protein and biodegradable plastic. Curr. Opin. Plant Biol., 8: 188-196.

SOMLEVA, M N; SNELL, K D; BEAULIE, J J; PEOPLES, O P; GARRISON, B R and PATTERSON, N A (2008). Production of polyhydroxybutyrate in switchgrass, a value-added co-product in an important lignocellulosic biomass crop. Plant Biotechnol. J., 6: 663-678.

SOMLEVA, M N; PEOPLES, O P and SNELL, K D (2013). PHA bioplastics, biochemicals, and energy from crops. Plant Biotechnol. J., 11: 233-252.

SURIYAMONGKOL, P; WESELAKE, R; NARINE, S; MOLONEY, M and SHAH, S (2007). Biotechnological approaches for the production of polyhydroxyalkanoates in microorganisms and plants - a review. Biotechnol Adv., 25: 148-175.

TOPLAK, N; OKRSLAR, V; STANIC-RACMAN, D; GRUDEN, K and ZEL, J (2004). A high-throughput method for quantifying transgene expression in transformed plants with real-time PCR analysis. Plant Mol. Biol. Rep., 22: 237-250.

WILLIAMS, S F and PEOPLES, O P (1996). Biodegradable plastics from plants. Chemtech., 26: 38-44.

WROBEL, M; ZEBROWSKI, J and SZOPA, J (2004). Polyhydroxybutyrate synthesis in transgenic flax. $J$. Biotechnol., 107: 41-54.

YUNUS, A M M; HO, C L and PARVEEZ, G K A (2008). Construction of PHB and PHBV transformation vectors for bioplastics production in oil palm. $J$. Oil Palm Res. (Special Issue 2008): 37-55.

ZENG, Y and YANG, T (2002). RNA isolation from highly viscous samples rich in polyphenols and polysaccharides. Plant Mol. Biol. Rep., 20: 417a-417e.

ZHONG, H; TEYMOURI, F; CHAPMAN, B; MAQBOOL, S B; SABZIKAR, R; EL-MAGHRABY, Y; DALE, B and STICKLEN, M B (2003). The pea (Pisum sativum L.) rbcS transit peptide directs the Alcaligenes eutrophus polyhydroxybutyrate enzymes into the maize (Zea mays L.) chloroplasts. Plant Sci., 165: 455-462. 